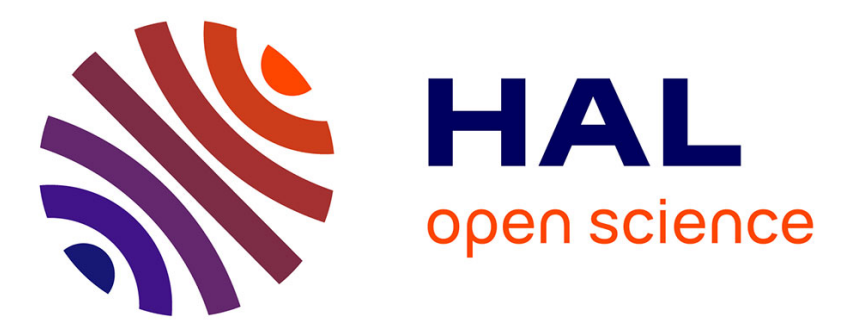

\title{
Very high-elevation Mont Blanc glaciated areas not affected by the 20th century climate change
}

Christian Vincent, Emmanuel Le Meur, Delphine Six, Martin Funk, M. Hoelzle, Suzanne Preunkert

\section{To cite this version:}

Christian Vincent, Emmanuel Le Meur, Delphine Six, Martin Funk, M. Hoelzle, et al.. Very highelevation Mont Blanc glaciated areas not affected by the 20th century climate change. Journal of Geophysical Research: Atmospheres, 2007, 112 (D09120), 1 à 9 p. 10.1029/2006JD007407 . insu00377491

HAL Id: insu-00377491 https://hal-insu.archives-ouvertes.fr/insu-00377491

Submitted on 11 Mar 2021

HAL is a multi-disciplinary open access archive for the deposit and dissemination of scientific research documents, whether they are published or not. The documents may come from teaching and research institutions in France or abroad, or from public or private research centers.
L'archive ouverte pluridisciplinaire HAL, est destinée au dépôt et à la diffusion de documents scientifiques de niveau recherche, publiés ou non, émanant des établissements d'enseignement et de recherche français ou étrangers, des laboratoires publics ou privés. 


\title{
Very high-elevation Mont Blanc glaciated areas not affected by the 20th century climate change
}

\author{
C. Vincent, ${ }^{1}$ E. Le Meur, ${ }^{1}$ D. Six,${ }^{1}$ M. Funk, ${ }^{2}$ M. Hoelzle, ${ }^{3}$ and S. Preunkert ${ }^{1}$ \\ Received 14 April 2006; revised 23 October 2006; accepted 13 December 2006; published 15 May 2007.
}

[1] This paper analyses the impact of climate change over the last 100 years on highelevation glaciated areas of the Mont Blanc range, comprising ice fields covering the top of the Mont Blanc (4808 m) and Dôme du Goûter $(4300 \mathrm{~m})$ areas. Surface ablation is negligible for these high-elevation areas and the surface mass balance is mainly controlled by snow accumulation. At Dôme du Goûter, ice fluxes have been calculated through two transversal sections by two independent methods in order to assess long-term surface accumulation. A comparison between these results and recent accumulation observations, together with the strong relationship between valley precipitation and snow accumulation, suggests that surface accumulation rates did not change significantly over the entire 20th century. Moreover, the small ice thickness changes, less than $3 \mathrm{~m}$ on the average, observed at Mont Blanc and Dôme du Goûter between 1905 and 2005 clearly reveal that these high-elevation glaciated areas have not been significantly affected by climate change over the last 100 years.

Citation: Vincent, C., E. Le Meur, D. Six, M. Funk, M. Hoelzle, and S. Preunkert (2007), Very high-elevation Mont Blanc glaciated areas not affected by the 20th century climate change, J. Geophys. Res., 112, D09120, doi:10.1029/2006JD007407.

\section{Introduction}

[2] The sensitivity of glacier mass balances to climate change is widely recognized [Intergovernmental Panel on Climate Change (IPCC), 2001; Oerlemans, 2001; Dyurgerov and Meier, 1999]. In the French Alps, the sensitivity of surface mass balance to climatic fluctuations has been assessed between $1600 \mathrm{~m}$ and $3600 \mathrm{~m}$ above sea level (a.s.l.) from field measurements carried out over the last decades [Vincent, 2002; Vincent et al., 2004]. Furthermore, the shrinkage of numerous glaciers in the Alps over the last century is reflected by field observations [Haeberli, 1995; Haeberli et al., 1998; Haeberli et al., 2002; Ohmura, 2004; Vincent et al., 2005] and satellite data [Paul et al., 2004; Berthier et al., 2004]. These studies show that glaciated areas below $3000 \mathrm{~m}$ a.s.l. have been strongly affected, especially over the last 2 decades. However, data on mass balance and thickness variations are rare for very high-elevation areas. Although some areas above $4000 \mathrm{~m}$ a.s.l. have been investigated over recent years by core drilling [Lüthi, 1999; Lüthi and Funk, 2001; Suter, 2002; Suter et al., 2001], no long-term observations are available for surface mass balance or thickness variations. The question remains as to whether these high-

\footnotetext{
${ }^{1}$ Laboratoire de Glaciologie et de Géophysique de 1'Environnement, Centre National de la Recherche Scientifique, Saint Martin d'Hères, France.

${ }^{2}$ Versuchsanstalt für Wasserbau, Hydrologie und Glaziologie, ETH Zentrum, Zürich, Switzerland.

${ }^{3}$ Department of Geography, University of Zürich-Irchel, Zürich, Switzerland.
}

Copyright 2007 by the American Geophysical Union. 0148-0227/07/2006JD007407 altitude areas have been affected by climate change over the last century and how the ice thickness has varied.

[3] To answer these questions, two ice fields in the Mont Blanc range, i.e., Dôme du Goûter (4300 m a.s.1.) and the summit of Mont Blanc (4808 m a.s.1) (Figure 1), have been investigated using field observations and old maps. At the altitude of Dôme du Goûter, the mean annual air temperature is $-11^{\circ} \mathrm{C}$ as inferred from ice temperatures at a depth of $30 \mathrm{~m}$ [Vincent et al., 1997; Suter, 2002]. Melting is close to zero and snow accumulation occurs throughout the year [Vincent et al., 1997]. Although some melting can occur in summer, it is limited to the top few millimeters of the snow pack. Rainfall is very rare and the surface mass balance (hereafter referred to as SMB) is dominated by accumulation and sublimation. The Mont Blanc ice cap is higher $\left(4808 \mathrm{~m}\right.$ a.s.l.) and colder $\left(-17^{\circ} \mathrm{C}\right.$ at a firn depth of $15 \mathrm{~m}$ ) [Vallot, 1913; C. Vincent, unpublished data, 2005] than the one at Dôme du Goûter. This paper investigates the relationship between the behavior of these two ice fields and climate change over the last 100 years.

[4] First, we describe the available data (section 2) for these areas. Second, ice fluxes are calculated from thickness and ice flow velocity measurements to infer the long term SMB at Dôme du Goûter (section 3). In section 4, recent annual surface mass balances as obtained from direct stakes reading are presented. Their strong correlations with precipitation measured at valley sites allows to compare long-term mean mass balances with precipitation trends (section 5). Finally, the thickness changes of these ice fields since the beginning of the 20th century, as reconstructed from old maps and recent geodetic observa- 


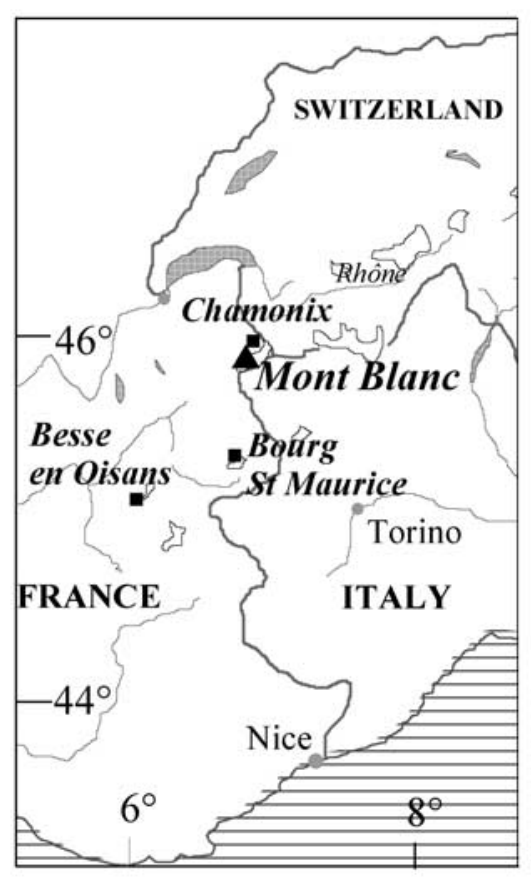

Figure 1. The French Alps. "Mont Blanc" on the map shows the location of the Mont Blanc and Dôme du Goûter ice fields. The Chamonix, Bourg St. Maurice, and Besse en Oisans meteorological stations are also plotted.

tions, confirm the absence of significant change (section 6) of the two ice caps.

\section{Description of Available Data}

[5] The first studies of snow and glaciers in the vicinity of the Dôme du Goûter and Mont Blanc ice fields were carried out by Joseph Vallot at the end of the 19th century [Vallot, 1913]. Moreover, Vallot et al. [1948] performed many topographic measurements in the Mont Blanc range in order to produce an accurate topographic map at a scale of 1:20,000. Between 1986 and 2004, several deep ice cores were drilled in the vicinity of Dôme du Goûter for geochemical purposes [e.g., Preunkert et al., 2000; Preunkert et $a l ., 2001]$. To interpret these ice cores, respective accumulation rates and ice flow velocities were measured in this area [Vincent et al., 1997]. For this purpose, $20-35 \mathrm{~m}$ long stakes were set up between 1993 and 2004 (Figure 2). Given the high accumulation values, the stakes often had to be replaced, sometimes two or three times a year. Moreover, many of the stakes were lost, buried in the snow. Consequently, the accumulation rate is not known for every year at all locations. To convert accumulation data into meters of water equivalent, the snow density was measured in pits and shallow drilling cores. Using the same stakes, the horizontal and vertical components of the velocities have been obtained from repeated topographic survey. In addition, extensive topographic measurements were performed in 2005 on Dôme du Goûter and Mont Blanc ice fields over surface areas of $240,000 \mathrm{~m}^{2}$ and $22,500 \mathrm{~m}^{2}$, respectively, in order to obtain an accurate digital elevation model.
[6] Radio echo soundings were made in June 1993 and completed in 1999 on Dôme du Goûter ice cap in order to determine the bedrock topography [Vincent et al., 1997; S. Suter, Dépouillement des sondages radar au Col du Dôme, Massif du Mont Blanc, du 1er au 5 juin 1993, Travail de stage pratique réalisé sous la responsabilité de M. Funk et de W. Haeberli, rapport non publié du VAW et de l'EPFZ de Zurich, 1993; S. Suter, unpublished data, 1999]. The Dôme du Goûter glacier bed is very rough with relatively deep, short, and narrow gullies. The ice thickness in this area ranges from $45 \mathrm{~m}$ to $140 \mathrm{~m}$. The field methods used to obtain accumulation, velocity and bedrock topography data have been fully described by Vincent et al. [1997].

\section{Long-Term Mass Balance Deduced From Ice Fluxes Calculated at Dôme du Goûter}

[7] In this section we will estimate the accumulation rate required to balance the ice fluxes at Dôme du Goûter. The ice fluxes have been calculated through two sections using thickness and surface ice flow velocity measurements. Using available accumulation, velocity, and glacier bed data, two drainage basin areas have been outlined based on ice flow direction and on the assumption that ice flow follows the steepest surface slopes (Figure 3). The ice flux from a western, WD, and an eastern drainage basin, ED, through respective cross sections has been calculated The glacier is cold, with negative temperatures (Figure 4) throughout the ice, and the sliding velocity is assumed to be zero [Paterson, 1994]. Consequently, the mean horizontal ice velocity through the cross section is derived from the analytical formulation proposed by Lliboutry [1981]:

$$
u(z, H)=((n+2) /(n+1)) u_{m}\left(1-(z / H)^{n+1}\right)
$$

where $u(z, H)$ is the horizontal velocity (m w.e. $\mathrm{yr}^{-1}$ ) at depth $z, H$ is the glacier thickness, $u_{m}$ is the mean velocity (m w.e. $\mathrm{yr}^{-1}$ ), and $n$ is the Glen flow law exponent. With $n=3$, the resulting mean horizontal velocity of each cross section is $80 \%$ of the horizontal surface velocity. Conversion into ice mass velocities is made with a mean snow density $(0.48 \pm 0.03)$ obtained from pit and core measurements (Figure 4). Ice fluxes are then computed by multiplying mean horizontal mass velocity with the crosssection area. Ice flux results are reported in Table 1. The results show that the necessary SMB to compensate the output flux from the west section is $2.1 \mathrm{~m}$ w.e. $\mathrm{yr}^{-1}$ on the average over the west drainage basin area, which is almost twice the value calculated for the east drainage basin area $\left(1.1 \mathrm{~m}\right.$ w.e. $\left.\mathrm{yr}^{-1}\right)$. These figures correspond to the long-term SMB and likely contain a high level of uncertainty related to the thickness, density, and velocity measurements, and the analytical formulation used to infer mean horizontal velocity in the cross section from horizontal surface velocity. The thicknesses and bedrock topography provided by radar measurements are relatively well known with an uncertainty of $\pm 5 \mathrm{~m}$ on the mean thickness of the cross section. Density measurements range from 0.45 to 0.51 in the top few meters and do not introduce large uncertainties in these calculations. The surface horizontal velocities have been obtained from stake position measurements using 


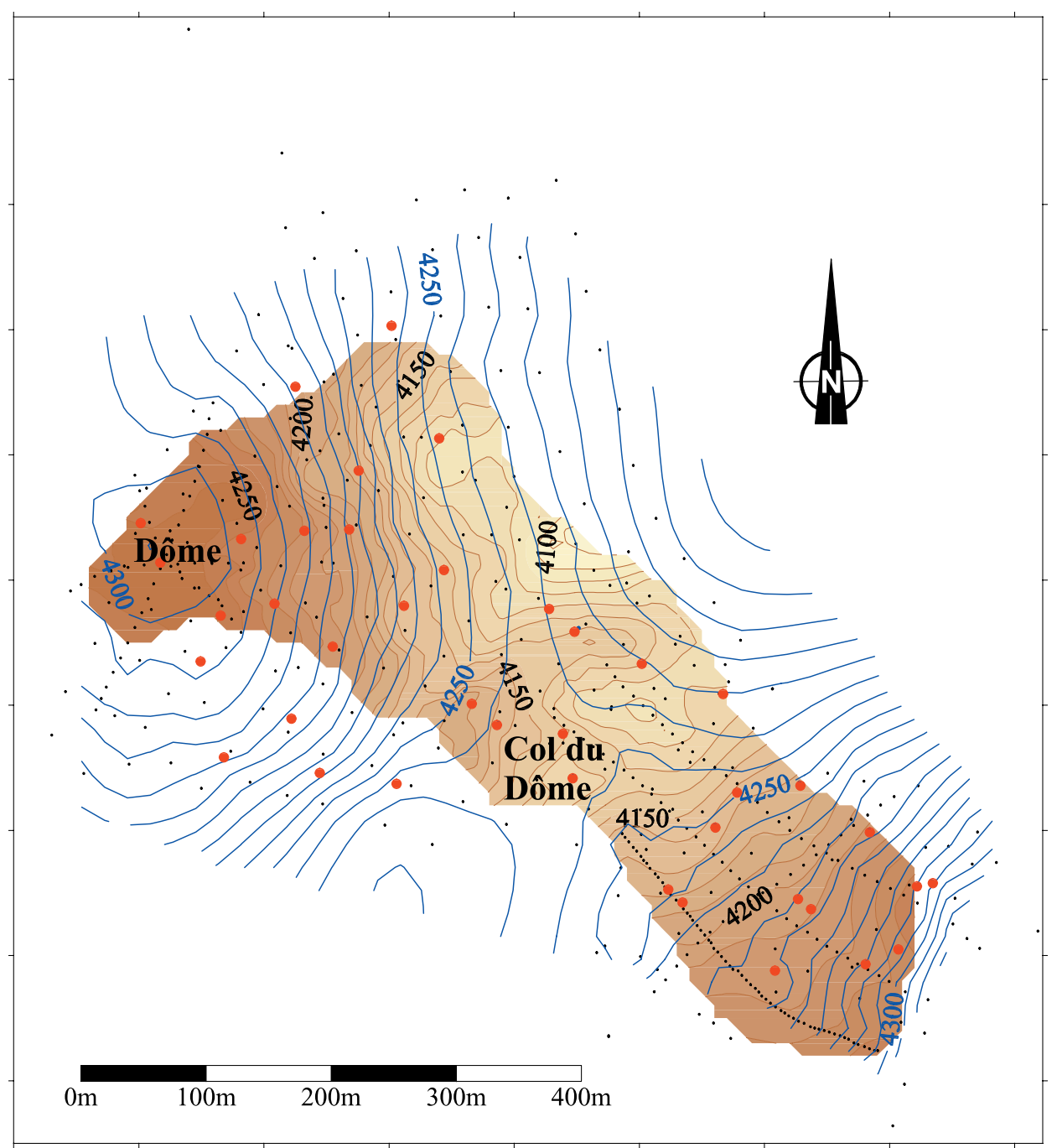

Figure 2. Surface and bedrock topographies of the Dôme du Goûter area. The large dots show the stake locations. Elevation differences between two contour lines are 5 and $10 \mathrm{~m}$ for the surface and bedrock, respectively.

differential GPS surveys or traditional topographical methods. Although the GPS or traditional topographical surveys are very accurate (few centimeters), the stakes tilt with time due to the creep of the snow. From repeated field campaigns carried out on the same stake network, it is possible to calculate that the horizontal surface velocity uncertainty is close to $0.5 \mathrm{~m} \mathrm{yr}^{-1}$. The drainage basin areas are probably known with an uncertainty of around $\pm 10 \%$. Using these uncertainties, an error calculation leads to a total uncertainty of $\pm 0.4 \mathrm{~m}$ w.e. $\mathrm{yr}^{-1}$ for the computed mean SMB for each drainage basin area. However, additional uncertainty arises from the lack of knowledge of firn deformation in the upper layers and consequently the analytical formulation given by Lliboutry [1981] used for the mean horizontal velocity calculation can be subject to question. For this reason, these calculated long-term SMBs must be checked by an independent method.

[8] The mean SMB can also be determined using the vertical velocity observations. Submergence velocities were calculated from $w s=w-u \tan \alpha$, where $u$ and $w$ are the measured horizontal and vertical components of the surface velocity and $\tan \alpha$ the surface slope [Paterson, 1994]. The submergence velocities obtained from repeatedly taken stake observations between 1993 and 2004 are plotted in Figure $5 \mathrm{f}$. These values have been integrated over the drainage basin areas using krigging interpolation to obtain the total submerging ice flux. Total submergence is $125,900 \mathrm{~m}^{3}$ w.e. $\mathrm{yr}^{-1}$ on WD and $57,000 \mathrm{~m}^{3}$ w.e. $\mathrm{yr}^{-1}$ on ED resulting in respective mean rates of 2.7 and $1.2 \mathrm{~m}$ w.e. $\mathrm{yr}^{-1}$ (Table 2). Assuming an uncertainty of \pm 0.03 for the density and $\pm 0.1 \mathrm{~m}$ for the vertical velocity component, the uncertainty of mean submergence velocities is $\pm 0.35 \mathrm{~m}$ w.e. $\mathrm{yr}^{-1}$. Given that each value results from two or three topographic surveys, the level of confidence is high.

[9] These results agree well with previous results obtained from the cross-section ice fluxes. Consequently, the submergence velocities, which do not depend on flow formulation, appear to offer a good way of assessing the long-term average SMB. Values obtained so far show only the long-term mean but do not allow to analyze interannual variations or trends over the respective time periods. Still, a few measured annual accumulation rates provide the link 


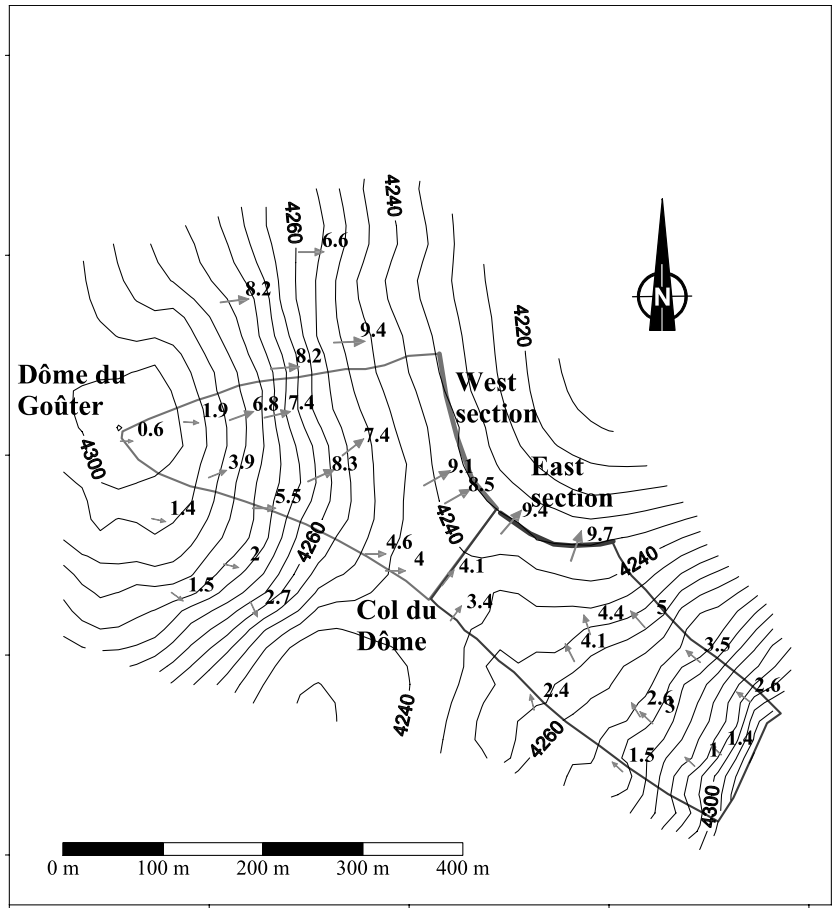

Figure 3. Mean observed horizontal velocities (19932004) at Dôme du Goûter $\left(\mathrm{m} \mathrm{yr}^{-1}\right)$. The two drainage basin areas (west and east) used for the ice flux calculations are shown on the figure.

between mass accumulation at the high summit domes and precipitation records from valley stations.

\section{Short-Term Surface Mass Balance}

[10] Snow accumulation measurements are not available at every site for each year due to access restrictions, high accumulation rates, and the difficulties involved in replacing the stakes. However, accumulation data are available in the western part of Col du Dôme for the years 1993-1994, 1994-1995, 1997-1998, and 1998-1999 (Figure 5). The most striking feature of Figure 5 is the high spatial gradients of accumulation. The Dôme du Goûter summit is exposed to strong winds predominately from south or southwest. This results in very low accumulation rates on the summit with less than $0.6 \mathrm{~m}$ w.e. $\mathrm{yr}^{-1}$, whereas they can reach up to $3 \mathrm{~m}$ w.e. $\mathrm{yr}^{-1}$ in the immediate lee of the summit dome. Although total accumulation varies from year to year, the patterns of spatial distribution vary little as can be seen from the 4 years example in Figures $5 \mathrm{a}-5 \mathrm{~d}$. The average accumulation over the 4 years (Figure $5 \mathrm{e}$ ) is in good agreement with the submergence rates (Figure 5f).

[11] The latter represent the long-term average SMBs, which can be easily used to obtain reliable mean accumulation values during several decades over the area. By contrast to accumulation data, submergence velocity data only requires topographic measurements over a few months. From mass balance observations (Figures $5 \mathrm{a}$ to $5 \mathrm{~d}$ ), average accumulations within this area of $2.00,2.46,1.94$, and $2.44 \mathrm{~m}$ w.e. $\mathrm{yr}^{-1}$ have been calculated for the years $1993-$ 1994, 1994-1995, 1997-1998, and 1998-1999, respectively. Finally, the mean accumulation over these 4 years is $2.21 \mathrm{~m}$ w.e. $\mathrm{yr}^{-1}$, very close to the average

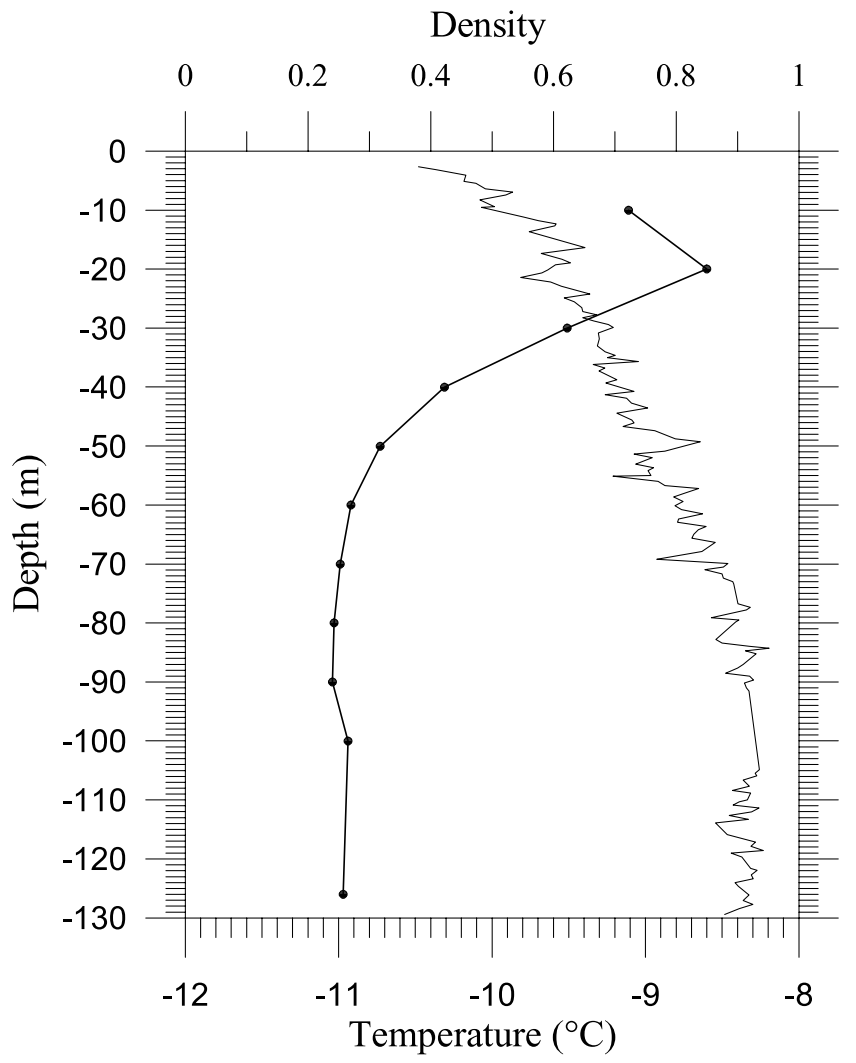

Figure 4. Snow/ice density and temperature versus depth from drilling core data at Dôme du Goûter in 1994.

submergence velocity $\left(2.16 \mathrm{~m}\right.$ w.e. $\left.\mathrm{yr}^{-1}\right)$ over the area. This last figure is the result of averaging over the area represented in Figure 5, which is different from the drainage basins of the previous section. This explains the difference with respect to the average submergence velocity $\left(2.7 \mathrm{~m}\right.$ w.e. $\left.\mathrm{yr}^{-1}\right)$ of the previous section. The good agreement between the average submergence velocity and the 4-years-averaged observed accumulation does not prove that Dôme du Goûter is in a steady-state, as the average accumulation results from only 4 years of observations. However, this analysis shows that the recent observed snow accumulation pattern is maintained from year to year and is similar to the long-term mass balance pattern. We will now assess the temporal accumulation variability and estimate the snow accumulation change

Table 1. Ice Flux Calculations for West and East Cross Sections, as Shown in Figure 3

\begin{tabular}{|c|c|c|}
\hline & West Cross Section & East Cross Section \\
\hline Width, m & 170 & 128 \\
\hline Mean thickness, $\mathrm{m}$ & 147 & 110 \\
\hline Cross-section area, $\mathrm{m}^{2}$ & 24,990 & 14,104 \\
\hline $\begin{array}{l}\text { Observed horizontal surface } \\
\text { velocity, } \mathrm{m} \mathrm{yr}^{-1}\end{array}$ & 9.8 & 9.5 \\
\hline $\begin{array}{l}\text { Horizontal surface velocity, } \\
\text { m w.e. } \mathrm{yr}^{-1}\end{array}$ & 4.7 & 4.6 \\
\hline $\begin{array}{l}\text { Mean horizontal velocity in } \\
\text { the section, } \mathrm{m} \text { w.e. } \mathrm{yr}^{-1}\end{array}$ & 3.8 & 3.6 \\
\hline $\begin{array}{l}\text { Flux in the section, } \\
\mathrm{m}^{3} \text { w.e. } \mathrm{yr}^{-1}\end{array}$ & 94,042 & 51,451 \\
\hline Drainage basin surface area, $\mathrm{m}^{2}$ & 45,940 & 46,800 \\
\hline $\begin{array}{l}\text { Computed mean surface mass } \\
\text { balance over the drainage } \\
\text { basin area, } \mathrm{m} \text { w.e. } \mathrm{yr}^{-1}\end{array}$ & 2.1 & 1.1 \\
\hline
\end{tabular}



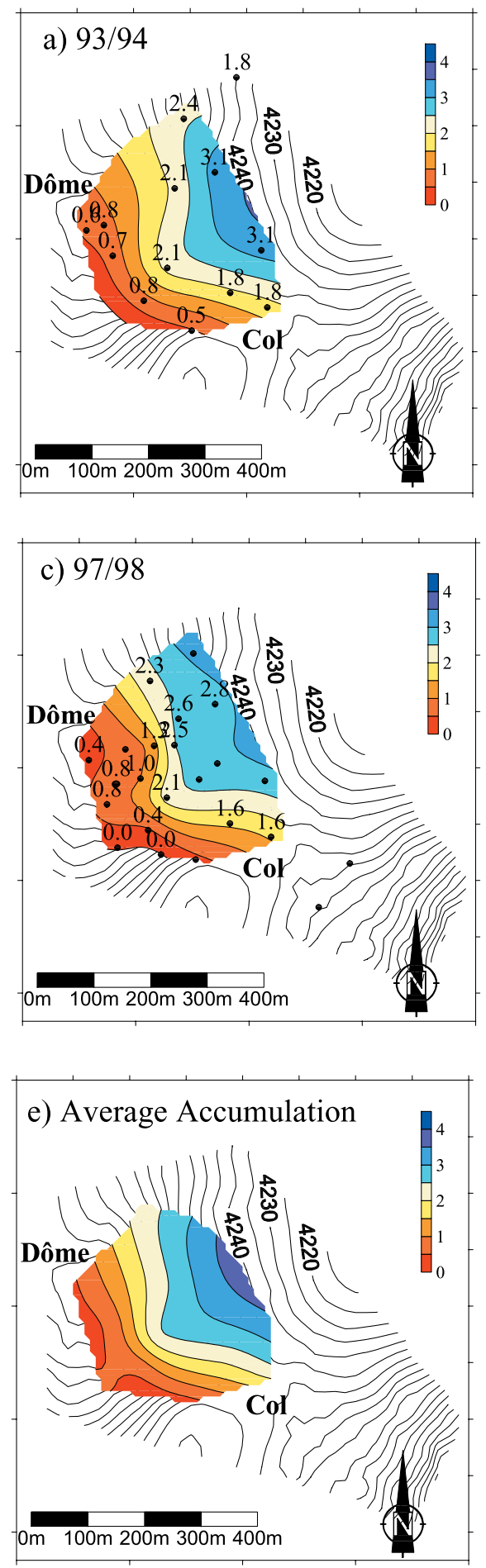
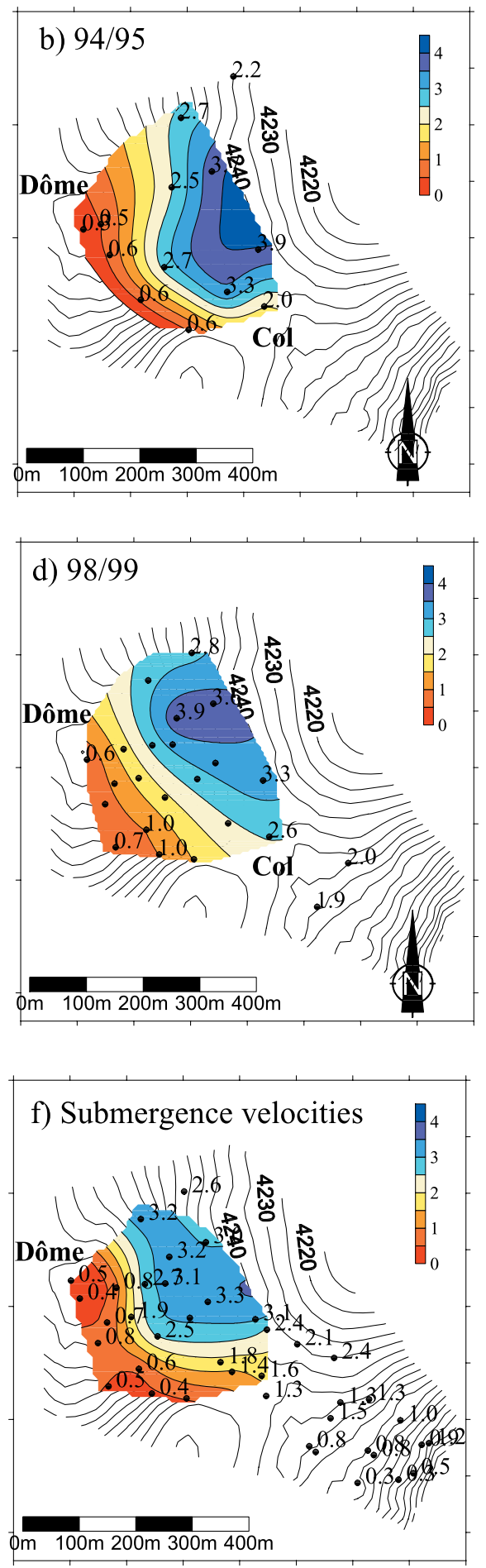

Figure 5. Observed annual accumulation for the years (a)1993-1994, (b)1994-1995, (c)1997-1998, and (d) 1998-1999, (e) average annual accumulation for the above years, (f) submergence velocities. All data are in $\mathrm{m}$ w.e. $\mathrm{yr}^{-1}$.

in the past. For this purpose, accumulation values have been compared to valley precipitation data.

\section{Correlation Between Surface Mass Balance and Valley Precipitation}

[12] The closest meteorological station is Chamonix, at an elevation of $1000 \mathrm{~m}$ a.s.l., and $8 \mathrm{~km}$ from Dôme du Goûter.
To compare high elevation accumulation and valley precipitation, a site with numerous accumulation observations has been selected. This site is located $130 \mathrm{~m}$ north of the Col du Dôme. Owing to the very high spatial accumulation variability, it is essential to analyze data originating from the same location. On this site, 22 observations are available for time periods ranging from 33 to 221 days between 1994 and 2004. These observations have been divided by the number 
Table 2. Ice Flux Calculations Over the West and East Drainage Basin Areas

\begin{tabular}{lcc}
\hline & $\begin{array}{c}\text { West Drainage } \\
\text { Basin Area }\end{array}$ & $\begin{array}{c}\text { East Drainage } \\
\text { Basin Area }\end{array}$ \\
\hline $\begin{array}{l}\text { Surface area, } \mathrm{m}^{2} \\
\text { Flux from integrated } \\
\quad \text { submergence velocities over the }\end{array}$ & 45,940 & 46,800 \\
$\quad$ surface, $\mathrm{m}^{3}$ w.e. $\mathrm{yr}^{-1}$ & 125,900 & 57,000 \\
$\begin{array}{l}\text { Computed mean surface mass } \\
\text { balance over the drainage } \\
\text { basin area, } \mathrm{m} \text { w.e. } \mathrm{yr}^{-1}\end{array}$ & 2.7 & 1.2 \\
\hline
\end{tabular}

of days to obtain mean daily accumulation, so the relationship between accumulation and valley precipitation does not depend on the elapsed time between readings. Data are plotted in Figure 6 and show a straightforward relationship between accumulation and valley precipitation. This relationship reveals a correlation coefficient of 0.73 and 0.76 for a linear regression and a power law regression, respectively. Note also that the spatial accumulation distribution depends strongly on wind influence. It is likely that this relationship is valid provided that the wind pattern over the last decade is representative of the long-term wind distribution. However, as a first approximation, one can assume that the total accumulation over the whole area of Dôme du Goûter is roughly related to the total precipitation at Chamonix and that the accumulation variability is similar to the annual precipitation variability. This assertion will be discussed in section 7 .

[13] The next step consists of investigating the precipitation variability observed at meteorological stations in valley

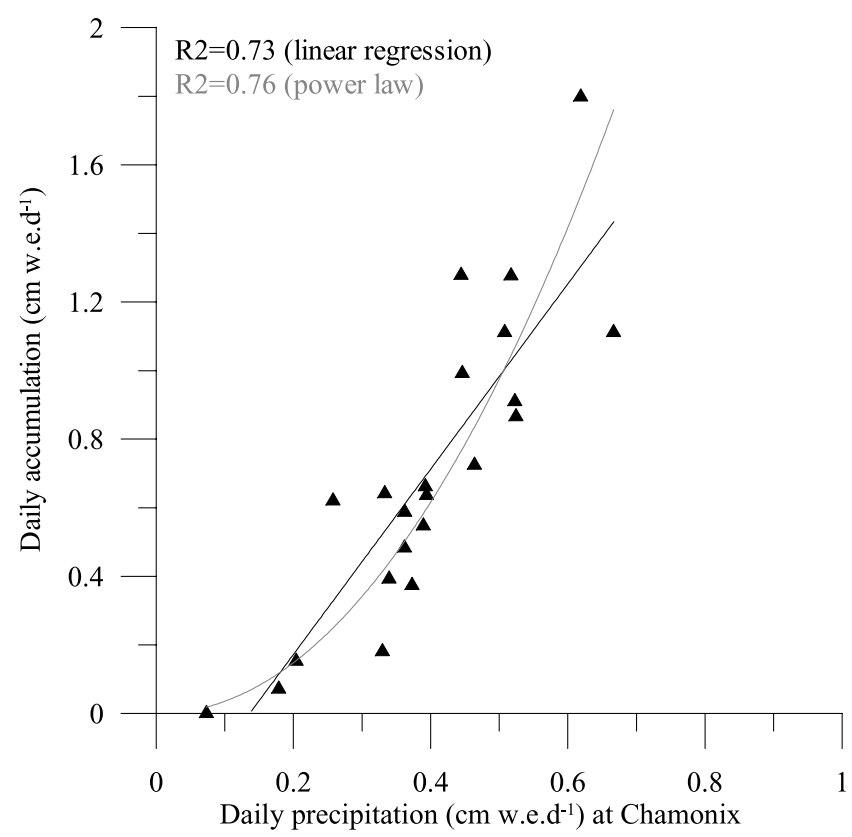

Figure 6. Relationship between observed Dôme du Goûter accumulation (cm w.e. $\mathrm{d}^{-1}$ ) and Chamonix precipitation $\left(\mathrm{cm}\right.$ w.e. $\left.\mathrm{d}^{-1}\right)$. This relationship has been established from 22 accumulation observations on a site $130 \mathrm{~m}$ North of the Col du Dôme. These observations were carried out for time periods ranging from 33 to 221 days and have been divided by the number of days.

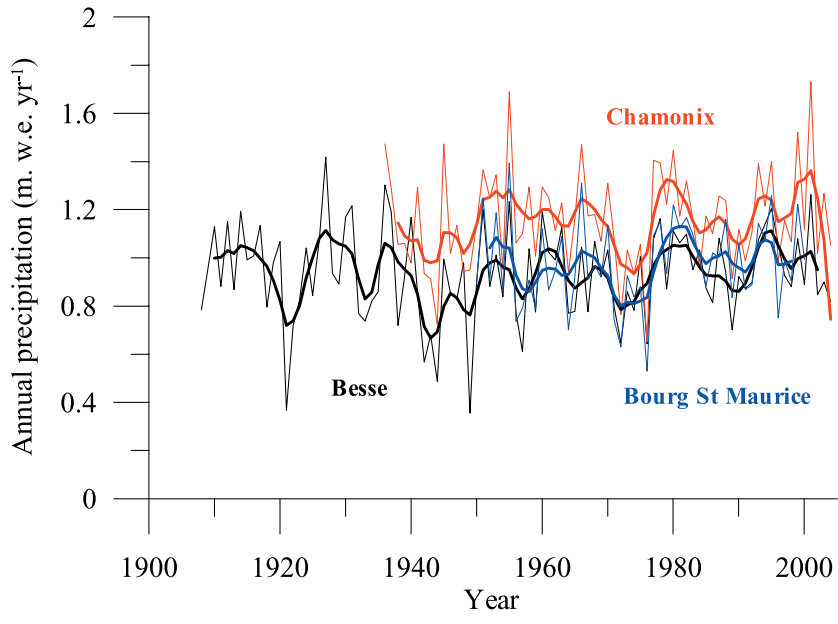

Figure 7. Annual precipitation ( $\mathrm{m}$ w.e. $\mathrm{yr}^{-1}$ ) over the 20th century for three meteorological stations in the French Alps. The curves show the 5-year running averages.

locations. For this purpose, the longest precipitation data series in the French Alps have been used, i.e., those of Besse en Oisans and Bourg Saint Maurice, $30 \mathrm{~km}$ and $95 \mathrm{~km}$ from Chamonix, respectively. This data, reported in Figure 7 , reveals a strong annual variability but a weak decadal variability. Although the meteorological stations are far away and although the Besse en Oisans and Bourg Saint Maurice precipitation rates are much lower than those of Chamonix, the 5-year average shows similar temporal changes. From this data, it can be seen that the decadal precipitation (not shown in Figure 7) did not vary by more than $\pm 10 \%$ over the 20 th century.

[14] At first glance, this assertion might seem to conflict with the results of previous studies. It has been shown that winter accumulation observed on the Sarennes glacier (Western Alps) increased by an average of $17 \%$ over the 1982-2002 period, compared to the 1954-1976 period [Vincent et al., 2004]. Moreover, the same study revealed that this winter accumulation rise was consistent with the winter precipitation (October to May) increase $(+15 \%)$ observed at the Western Alp meteorological stations. However, compared to the average over the whole 20th century, the 1977-2004 winter precipitation average is only $10 \%$ higher. In addition, by taking into account the total annual precipitation, which seems to be the main contribution to the SMB change above $4300 \mathrm{~m}$ a.s.1., the precipitation since 1977 is only $6 \%$ higher than the 20 th century average. As a result, we conclude that variability of valley precipitation on a decadal timescale is very low. From the relationship between high-altitude accumulation and valley precipitation, this result suggests that a small change in accumulation should be expected at very high altitude. However, the reliability of the relationship between snow accumulation and precipitation could be subject to question and these preliminary conclusions will have to be checked by other independent studies.

\section{Thickness Variations}

[15] Thickness variations have been deduced by comparing two digital elevation models computed from recent 


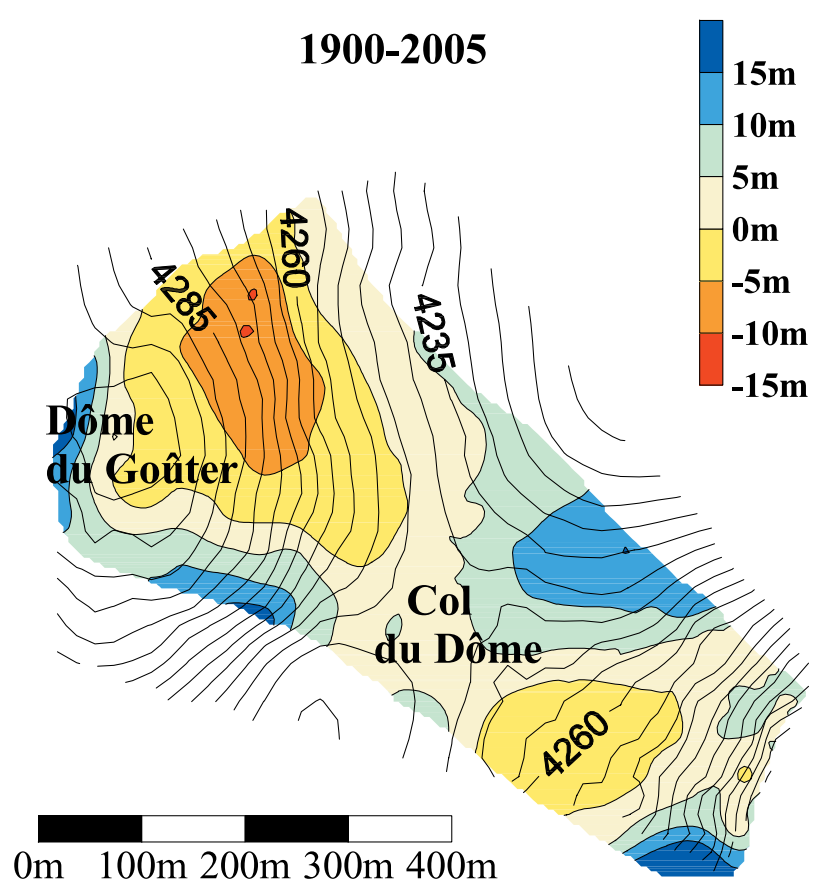

Figure 8. Thickness changes (m) at Dome du Goûter between 1905 and 2005, from an old map and recent geodetic measurements.

geodetic measurements and an old map dating back to the beginning of the 20th century. Measurements using differential GPS (Global Positioning System) were carried out in 2005 and are accurate to within a few centimeters. The old map [Vallot et al., 1948] was established in 1905. The accuracy of this map is unknown but the comparison of surface elevations on ice-free areas suggests that altitude is accurate to within a few meters. This data is available for the Mont Blanc and Dôme du Goûter ice fields. The results are reported in Figures 8 and 9. The most striking features of these figures are the small thickness changes observed over the 20th century. For both areas, thickness variations do not exceed $\pm 15 \mathrm{~m}$. The average changes are $+2.6 \mathrm{~m}$ at Dôme du Goûter and $-0.3 \mathrm{~m}$ at Mont Blanc. Considering the uncertainty interval, i.e., $\pm 5 \mathrm{~m}$ (yellow in Figures 8 and 9), it can be concluded that no significant thickness change is detectable over most of these areas. These results contrast with large changes observed on the tongues of the glaciers in the Mont Blanc area. For instance, the Mer de Glace glacier has thinned by more than $150 \mathrm{~m}$ at $1600 \mathrm{~m}$ a.s.l. since the beginning of the 20th century [Vincent, 2002]. More generally, in the Mont Blanc area, every glacier tongue below $2000 \mathrm{~m}$ a.s.l. thinned by more than $100 \mathrm{~m}$ since the beginning of the 20th century.

\section{Discussion}

[16] All these results suggest that the SMB at Dôme du Goûter and Mont Blanc did not experience any significant changes over the 20th century. However, before drawing firm conclusion about mass balance change over the 20th century for these high-elevation areas, several points deserve some comments.
[17] First, the relationship between accumulation and precipitation could be subject to question. It can be argued that precipitation and wind pattern have changed simultaneously and that the absence of accumulation change does not systematically reflect an absence of precipitation change. Indeed, just as wind patterns explain the high spatial accumulation variations on Dôme du Goûter, accumulation changes with time could be related to wind direction changes. However, on Dôme du Goûter, measurements were carried out over a large surface area with different expositions. Consequently, the SMB changes in time are likely to be representative of the precipitation changes in these high-elevation areas.

[18] Second, the absence of thickness changes in high accumulation zones does not provide absolute proof of a steady SMB. Indeed, as demonstrated below, ice thickness change observations do not closely reflect SMB data. In fact, it can be argued that an ice flux increase (decrease) resulting from a SMB rise (drop) could lead to an ice flow velocity increase (decrease) with almost no thickness change. The influence of temperature change on the ice flow could also be subject to question, as the deformation rate of ice depends greatly on temperature. However, for this negative temperature $\left(-11^{\circ} \mathrm{C}\right.$ at Dôme du Goûter and $-17^{\circ} \mathrm{C}$ at Mont Blanc), the change in flow parameter is less than $10 \%$ per ${ }^{\circ} \mathrm{C}$ [Paterson, 1994, p. 97]. Given that secular warming is $+1{ }^{\circ} \mathrm{C} /$ century in the Alps [Böhm et al., 2001], temperature change cannot influence ice flow significantly. However, the most important is the relationship between thickness change and ice flux. As can be seen in Figure 4, the ice temperature is below zero from the surface to bedrock. As a consequence, the glacier is frozen to its bed and no sliding occurs. According to Glen's flow law and the laminar flow assumption [Paterson, 1994, p. 251], the depth averaged horizontal ice velocity is proportional to $\alpha^{3}$ and $H^{4}$ and therefore the ice flux to $\alpha^{3}$ and $H^{5}$,where $\alpha$ is the surface slope and $H$ is the glacier thickness. This means that, to a first-order approximation and in the absence of

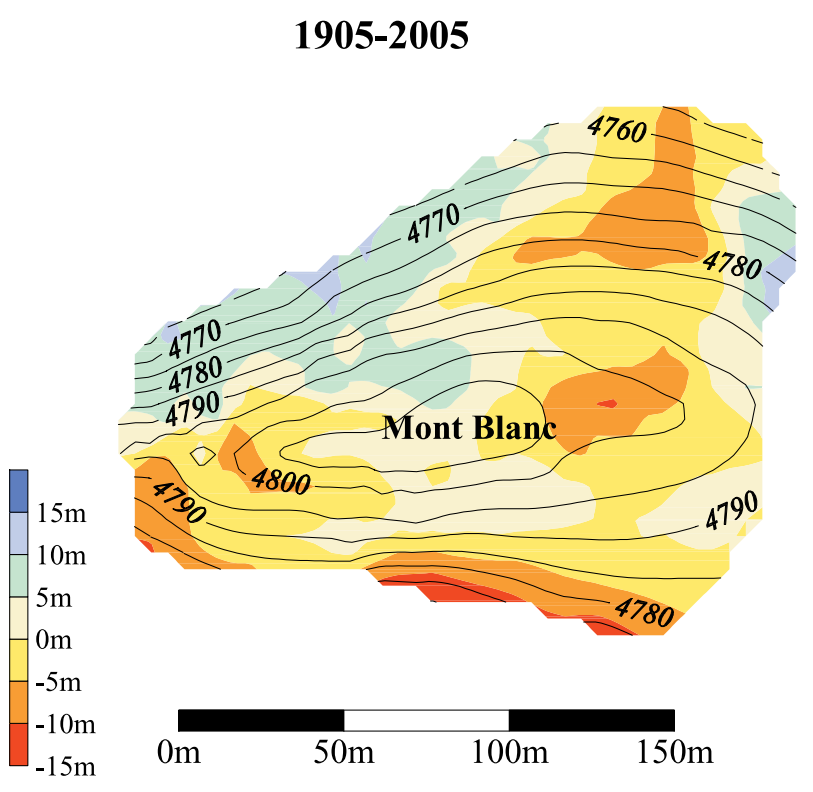

Figure 9. Thickness changes $(\mathrm{m})$ on the Mont Blanc ice cap between 1905 and 2005 . 
large slope changes with time, the relative change in ice thickness is $1 / 5$ of the relative flux change or relative change in SMB. Therefore the ice thickness is not highly sensitive to SMB. For instance, a thickness change greater than $10 \%$ on the Dome du Goûter ice cap would require a SMB change of more than $50 \%$.

[19] In the future, the influence of climate change on these high-elevation glaciated areas could be different. Over the next 100 years, according to climate scenarii [IPCC, 2001], the temperature could increase within a range of +1.5 to $+6^{\circ} \mathrm{C}$. The impact such conditions could have on precipitation quantities remains unknown. However, the change in temperature would definitely affect the precipitation phase. During the summer, a significant part of precipitation would be liquid above $4300 \mathrm{~m}$ a.s.l. and would percolate into the firn. In addition, the meltwater resulting from summer surface melting could also percolate into the snow and refreeze in the deep layers. This process, far more efficient than heat conduction, would raise the temperature of the firn. In this way, the ice temperature at the bed could reach the melting point much more quickly than by mere heat conduction and the glacier could start to slide over its bed. Consequently, the dynamics of the glacier could be entirely modified.

\section{Conclusions}

[20] Geodetic measurements carried out in 1905 and 2005 on the highest ice fields of the Mont Blanc range indicate small thickness changes and show that these very highelevation glaciated areas have not been significantly affected by climate change over the last 100 years.

[21] At Dôme du Goûter, ice fluxes calculated from horizontal velocities and thickness measurements through two cross sections agree well with the ice fluxes determined from submergence velocity measurements. These ice fluxes allowed us to determine the long-term SMB over this area. Moreover, the average 4-year accumulation observations are close to this long-term SMB and show the same spatial pattern. The comparison between observed accumulation and valley meteorological data suggests a low decadal variability of snow accumulation and no SMB trend over the 20th century. Given that (1) the long term accumulation rate, calculated from ice fluxes or submergence velocities, is very close to the average accumulation rate observed over the period 1993-1995 and 1997-1999, (2) there is a good relationship between the accumulation change at Dome du Goûter and the valley precipitation change, and (3) the 1993-1995 and 1997-1999 mean valley precipitation rate (1.35 m w.e. $\left.\mathrm{yr}^{-1}\right)$ is close to the 20 th century mean precipitation rate $\left(1.26 \mathrm{~m}\right.$ w.e. $\left.\mathrm{yr}^{-1}\right)$, we can conclude that the Dôme du Goûter SMB did not change significantly over the whole 20th century. Although thickness changes are not highly sensitive to accumulation changes, these results concerning accumulation could explain the very small changes observed at high altitudes on these ice fields. In any case, this study reveals that the very high-elevation ice fields in the Mont Blanc area have not been affected by the climate warming. The 20 th century climate warming affected the atmospheric temperature in the Alps by $+1^{\circ} \mathrm{C}[$ Böhm et al., 2001]. However this change did not significantly affect the ice deformation rate in the high-altitude ice fields since the ice temperature remains far below the melting point and therefore keeping the glacier frozen to its bed.

[22] Over the next 100 years, according to climate warming scenarii, a significant part of precipitation could become rain above $4300 \mathrm{~m}$ a.s.l. which could warm up the deep firn and ice. Some studies show that substantial warming of the firn temperature at shallow depths has taken place over the last few decades [Lüthi and Funk, 2001; Suter et al., 2001]. Should this warming reach the bottom ice, the ice dynamics would be greatly modified. This question will be closely examined in a subsequent study based on ice temperature data for Dôme du Goûter glacier, from measurements in deep drill holes over the last decade.

[23] Acknowledgments. The authors would like to thank all those who took part in collecting the extensive field measurements on these glaciers, especially those who suffered altitude sickness. This study has been funded by Observatoire des Sciences de l'Univers de Grenoble (OSUG) and by the European Programs ALPCLIM and CARBOSOL. This work was also supported by the city of Chamonix Mont-Blanc. We thank the town council of Chamonix for providing an authorization to carry out field measurements on the top of Mont Blanc. We thank also Météo-France for providing meteorological data.

\section{References}

Berthier, E., Y. Arnaud, D. Baratoux, C. Vincent, and F. Rémy (2004), Recent rapid thinning of the Mer de Glace glacier derived from satellite optical images, Geophys. Res. Lett., 31, L17401, doi:10.1029/ 2004GL020706.

Böhm, R., I. Auer, M. Brunetti, M. Maugeri, T. Nanni, and W. Schöner (2001), Regional temperature variability in the European Alps 17601998, Int. J. Climatol., 21, 1779-1801.

Dyurgerov, M. B., and M. F. Meier (1999), Analysis of winter and summer glacier mass balances, Geogr. Ann., Ser. A, 81, 541-554.

Haeberli, W. (1995), Glacier fluctuations and climate change detection, Geogr. Fis. Dinam. Quat., 18, 191-199.

Haeberli, W., M. Hoelzle, S. Suter, and R. Frauenfelder, (Compilers) (1998), Fluctuations of Glaciers, 1990-1995, vol. VII, U. N. Educ. Sci. Cult. Org., Paris.

Haeberli, W., M. Maisch, and F. Paul (2002), Mountain glaciers in global climate-related observation networks, World Meteorol. Org. Bull., 51(1), $1-8$.

Intergovernmental Panel on Climate Change (IPCC) (2001), Climate Change 2001: The Scientific Basis: Contribution of Working Group I to the Third Assessment Report of the Intergovernmental Panel on Climate Change, edited by J. T. Houghton et al., 881 pp., Cambridge Univ. Press, New York.

Lliboutry, L. (1981), A critical review of analytical approximate solutions for steady state velocities and temperatures in cold ice sheets, Z. Gletscherkd. Glazialgeol., 15, 135-148.

Lüthi, M. (1999) Flow modeling and rheological investigations of cold firn: A case study at Colle Gnifetti, Ph. D. thesis, Versuchsanstalt für Wasserbau, Hydrologie und Glaziologie, ETH Zurich, Switzerland.

Lüthi, M., and M. Funk (2001), Modelling heat flow in a cold, high-altitude glacier: Interpretation of measurements from Colle Gnifetti, Swiss Alps, J. Glaciol., 47, 314-324.

Oerlemans, J. (2001), Glaciers and Climate Change, A. A. Balkema, Brookfield, Vt.

Ohmura, A. (2004), Cryosphere during the Twentieth Century, in The State of the Planet. Frontiers and Challenges in Geophysics, IUGG Geophys. Monog., 150, 239-257.

Paterson, W. S. B. (1994), The Physics of Glaciers, 3rd ed., Elsevier, New York.

Paul, F., A. Kääb, M. Maisch, T. Kellenberg, and W. Haeberli (2004), Rapid disintegration of Alpine glaciers observed with satellite data, Geophys. Res. Lett., 31, L21402, doi:10.1029/2004GL020816.

Preunkert, S., D. Wagenbach, M. Legrand, and C. Vincent (2000), Col du Dôme (Mt Blanc Massif, French Alps) suitability for ice core studies in relation with past atmospheric chemistry over Europe, Tellus, Ser. B, 52, 993-1012.

Preunkert, S., M. Legrand, and D. Wagenbach (2001), Sulfate trends in a Col du Dôme (French Alps) ice core: A record of anthropogenic sulfate levels in the European mid-troposphere over the 20th Century, J. Geophys. Res., 106, 31,991-32,004. 
Suter, S. (2002), Cold firn and ice in the Monte Rosa and Mont Blanc areas: Spatial occurrence, surface energy balance and climate evidence, $\mathrm{Ph}$. D.thesis, Versuchsanstalt für Wasserbau, Hydrologie und Glaziologie, ETH Zürich, Switzerland.

Suter, S., M. Laternser, W. Haeberli, M. Hoelzle, and R. Frauenfelder (2001), Cold firn and ice of high-altitude glaciers in the Alps: Measurements and distribution modeling, J. Glaciol., 47, 85-96.

Vallot, H., J. Vallot, and C. Vallot (1948), Cartes du Massif du Mont Blanc à l'échelle du 1:20 000, Edition Girard, Barrère et Thomas, France.

Vallot, J. (1913), Valeur et variations de la température profonde du glacier au Mont Blanc, C. R. Hebd. Séances Acad. Sci. (Paris), 156(20), 15751578 .

Vincent, C. (2002), Influence of climate change over the 20th Century on four French glacier mass balances, J. Geophys. Res., 107(D19), 4375, doi:10.1029/2001JD000832.

Vincent, C., M. Vallon, J. F. Pinglot, M. Funk, and L. Reynaud (1997), Snow accumulation and ice flow at Dôme du Goûter $(4300 \mathrm{~m})$, Mont Blanc, French Alps, J. Glaciol., 43, 513-521, (Erratum, J. Glaciol., 44, 194, 1998.)
Vincent, C., G. Kappenberger, F. Valla, A. Bauder, M. Funk, and E. Le Meur (2004), Ice ablation as evidence of climate change in the Alps over the 20th Century, J. Geophys. Res., 109, D10104, doi:10.1029/ 2003JD003857.

Vincent, C., E. Le Meur, D. Six, and M. Funk (2005), Solving the paradox of the end of the Little Ice Age in the Alps, Geophys. Res. Lett., 32, L09706, doi:10.1029/2005GL022552.

M. Funk, Versuchsanstalt für Wasserbau, Hydrologie und Glaziologie, ETH Zentrum, Zürich, Switzerland.

M. Hoelzle, Department of Geography, University of Zürich-Irchel, Zürich, Switzerland.

E. Le Meur, S. Preunkert, D. Six, and C. Vincent, Laboratoire de Glaciologie et de Géophysique de l'Environnement, Centre National de la Recherche Scientifique, 54 rue Molière, BP 96, F-38402 Saint Martin d'Hères, France. (vincent@lgge.obs.ujf-grenoble.fr) 